\title{
THE ROLE OF FINANCIAL EDUCATION IN ADOLESCENT CONSUMERS' FINANCIAL KNOWLEDGE ENHANCEMENT
}

\section{FINANCIJSKIM OBRAZOVANJEM DO POVEĆANJA ZNANJA O FINANCIJAMA POTROŠAČA ADOLESCENATA}

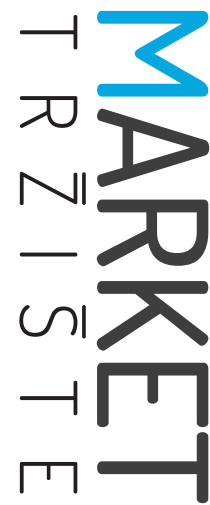

Market-Tržište

Vol. 32, Special Issue, 2020, pp. 115-130

UDK 336:37-053.6

DOl http://dx.doi.org/10.22598/mt/2020.32.spec-issue.115

Preliminary communication

\begin{abstract}
Andrea Lučića, Dajana Barbićc ${ }^{b}$ Marija Uzelac ${ }^{c}$
${ }^{a}$ University of Zagreb, Faculty of Economics and Business Zagreb, Trg J. F. Kennedyja 6, 10000 Zagreb, CROATIA, e-mail: andrea.lucic@efzg.hr

${ }^{b}$ University of Zagreb, Faculty of Economics and Business Zagreb, Trg J. F. Kennedyja 6, 10000 Zagreb, CROATIA, e-mail:dbarbic@efzg.hr

c University of Zagreb, Faculty of Economics and Business Zagreb, Trg J. F. Kennedyja 6, 10000 Zagreb, CROATIA, e-mail: marija.uzelac7@gmail.com
\end{abstract}

\begin{abstract}
Purpose - The aim of this paper was to challenge the purpose of financial education in the context of financial literacy of adolescents, and to test the efficiency of the developed high-school study book and program "My money, my future". Also, the purpose was to identify the predictors of financial knowledge before conducting the workshop, as well as the characteristics of adolescents with best performances on the financial knowledge test.
\end{abstract}

Design/Methodology/Approach - The data was collected from a purposive sample of teenagers who participated in "My money, my future" program from October 2016 to February 2018 and the questionnaire employed was a three-part tool.

Findings and implications - Financial interventions contribute to young people's financial knowledge. Interest, previous financial education and ownership of a bank account were found to be valid and reliable predictors of higher levels of knowledge among teenagers. Furthermore, most high school students in the sample reported they had already engaged in saving behaviour, and more than half of them claimed to have bank accounts. Financial knowledge after the workshop

\section{Sažetak}

Svrha - Cilj je članka istražiti utjecaj financijskog obrazovanja na financijsku pismenost adolescenata i testirati učinkovitost srednjoškolskog udžbenika i programa „Moj novac, moja budućnost“. Također, svrha je provedenog istraživanja identificirati prediktore financijskog znanja prije radionice, kao i karakteristike mladih s najboljim rezultatima kako bi se dodatno istražila učinkovitost financijskog obrazovanja.

Metodološki pristup - Istraživanje je provedeno na adolescentima koji su sudjelovali u radionici "Moj novac, moja budućnost" od listopada 2016. do veljače 2018. godine te je korišten upitnik kao instrument istraživanja.

Rezultati i implikacije - Provedenim istraživanjem zaključeno je kako financijske intervencije pridonose znanju mladih. Kao prediktori veće razine znanja među tinejdžerima navode se interesi, prijašnje financijsko obrazovanje i vlasništvo bankovnog računa. Nadalje, većina srednjoškolaca u uzorku ima razvijene štedne navike i ponašanje $u$ kontekstu štednje te ima otvorene račune u bankama. Istraživanje razine financijskog znanja analizirano je u dvije faze, prije i nakon održane radionice (predtest i posttest). Nalazi ukazuju na to kako je financijsko znanje nakon radionice značajno veće 
was significant compared to their knowledge before the workshop. Greater knowledge before the workshop led to significantly higher levels of knowledge afterwards. Differences in the levels of financial knowledge were also tested with respect to gender.

Limitations - The sample only includes high-school students and the research was conducted exclusively on the territory of the Republic of Croatia.

Originality - The paper emphasized the importance of financial education programs in increasing the level of financial literacy and efficiency of future financial decision making among adolescents.

Keywords - financial education, financial literacy, financial knowledge, young adults, Croatia od znanja prije sudjelovanja u radionici te kako je veće znanje prije radionice dovelo do znatno veće razine znanja nakon radionice. Razlika u razinama znanja istražena je i s obzirom na spol ispitanika.

Ograničenja - Uzorak uključuje samo učenike srednjih škola, a istraživanje je provedeno isključivo na području Republike Hrvatske.

Doprinos - Članak naglašava važnost programa financijskog obrazovanja za unaprjeđenje razine financijske pismenosti i učinkovitosti donošenja financijskih odluka u budućnosti.

Ključne riječi - financijsko obrazovanje, financijska pismenost, financijsko znanje, mladi, Hrvatska. 


\section{INTRODUCTION}

In both theory and practice, financial knowledge and financial skills that make financial literacy are crucial for understanding and learning about financial concepts and objects (Barbić, Lučić \& Chen, 2019). In other words, it is the ability to understand information in the context of finances and the capacity to make the right financial decision (Luksander, 2014). Moreover, a lack of financial literacy is a limiting factor in managing personal finances successfully, and may lead to the absence of personal budget planning and lack of understanding of financial markets (Lewis \& Messy, 2012). Consumers with high and evolving levels of financial literacy have the capacity to make efficient financial decisions about their spending and saving. They understand basic financial concepts, such as the influence of interest rates on borrowing and saving, the concept of credit rating and the importance of savings for retirement (Gerhard, Gladstone \& Hoffmann, 2018). Consequently, consumers are able to make their financial futures secure. Due to a great importance of financial literacy and knowledge for future financial stability, it is crucial to invest in financial education from a young, i.e. adolescent age. In other words, young people who adopt basic habits crucial for managing personal finances exhibit a tendency to achieve financial security in their adulthood (Moffitt et al., 2011).

Many students, regardless of the levels of economic and financial development of the country they live in, demonstrate very basic levels of financial knowledge and skills. More than 15\% of students in the participating OECD countries and economies perform below the baseline level of proficiency. They are able to manage only the most basic financial tasks, such as recognizing the difference between needs and wants or comparing values of goods based on their prices (OECD, 2014 cited in Lusardi, 2015). It is crucially important to improve financial literacy levels of the low-performing students in order to enable their future participation in economic life as adults.

Arising from low levels of financial literacy of Croatian consumers, especially the young ones, the aim of this paper is: (1) to challenge the purpose of financial education for the financial literacy of adolescents and to test the efficiency of the developed high-school study book and program "My money, my future"; (2) to identify the predictors of financial knowledge, as well as the characteristics of adolescents with the best performance on the financial knowledge test, to further investigate the process of financial education effectiveness.

The findings of this study carry implications for consumer educators to develop and implement high-quality financial education programs for young adults, based on specific characteristics which might stimulate the learning process. Financial education programs are frequently not based on textbook literature on the specific personal finance topics necessary for the development of both financial knowledge and financial skills, but are rather founded on various types of non-systematic literature sources (numerous papers, books, websites, newspaper articles, etc.) gathered by financial literacy educators. Thereby, the contribution of this paper lies in analysing results which disclose whether this type of education (book-based educational workshop) is efficient and valuable, to what extent, and if it should be promoted to continued use within financial education programs.

\section{THEORETICAL BACKGROUND}

\subsection{Financial literacy of adolescent consumers}

Today's adolescents belong to the Generation Z. They have very specific attitudes and expectations as consumers, as employees and as citizens (Gaidhani, Arora \& Sharma, 2019). Generation $Z$, also called the digital generation, is

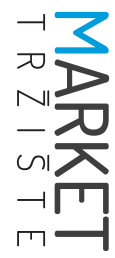




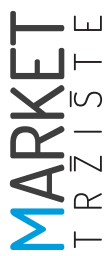

comprised of people born after 1995. Members of this generation were born when technological development was already in full swing, so social networks are of great importance for their communication and information sharing (Berkup, 2014). Due to their connection with technology, they are exposed to great amounts of information on a daily basis. Therefore, adolescents are self-directed learners who are evolving together with the technology and who have specific learning characteristics and preferences. Their learning process is much more efficient during observation and actual application than it would be via traditional learning methods, such as reading and listening (Shatto \& Erwin, 2016). Also, they prefer instant feedback from their lecturers and personalized learning methods (Wiedmer, 2015). Finally, their involvement in financial education is much greater than any previous generation's, and they find financial education programs a very important source of personal finance information (Raddon A Fiserv Company, 2017).

According to a research from the Center for Generational Kinetics (2018), adolescents shape their attitudes toward personal finances at an early age. Although their main source of income is the allowance they receive from parents, they make purchase decision on their own. They understand the significance of saving and, while making purchasing decisions, keep in mind the effect that purchasing has on savings (TransUnion, 2017). Also, adolescents are aware of the need to avoid debt and eliminate or limit buying products and services with borrowed money and deferred payment cards (Center for Generational Kinetics, 2017), which has a great impact on developing positive financial habits. Furthermore, they understand the importance of financial literacy in effective management of their personal finances, and recognize that strengthening financial literacy is a crucial factor in achieving financial success in the future. The main source of information necessary for developing adolescents' financial knowledge are their parents. In conversations with them, adolescents learn about spending, saving and personal finances in general (Center for Generational Kinetics, 2017), which has a positive influence on their financial literacy (Ali et al., 2014). They observe the parents' habits, behaviours and financial status in the process of making financial decisions and, consequently, create their own attitudes and expand their knowledge on personal finances. Thus, parents strongly influence their children's financial future (Synchrony Financial, 2018). The second most important source of information for adolescents are schools. Through various programs of financial education and economics in general, educational institutions are improving adolescents' financial literacy. Their peers, siblings, social networks, media and mobile applications are also among the most important sources of information for the development of their financial literacy (TransUnion, 2017).

Furthermore, according to Chaston (2012), adolescents are optimistic about their financial future (as cited in Vojvodić, 2018), they believe they will be able to finance their own monthly expenses and will have enough money to spend, pay off their debts and have a carefree retirement (Vision Critical, 2019). Most adolescents do save, usually for specific goals (TransUnion, 2017), and are confident about their financial stability (Nielsen, 2015). In the context of making financial decisions, optimism and self-confidence indicate individuals' optimistic attitudes toward their financial performance. On the other hand, according to the Croatian National Bank's survey on financial literacy, the average score of financial literacy in Croatia is 11.7, out of 21 points, and the lowest score of 9.3 points is obtained by respondents younger than 19 (Croatian National Bank [CNB], 2015). This implies worryingly low levels of financial literacy, as well as vulnerability of the young. To enhance the level of young consumers' financial literacy, it is crucial to invest in their financial knowledge using financial education and thereby protecting them as consumers. 


\subsection{Efficiency of financial education programmes among adolescents}

Financial education is crucial for the increase of financial literacy levels among adolescents and for creating responsible and financially literate consumers. The overarching purpose of consumers' financial education is to improve their knowledge and financial decision making so that they could reach financial well-being (Braunstein \& Welch, 2002). In today's stimulating financial environment, it is crucial for adolescent consumers to recognize and learn how to deal with challenging decisions related to money. Adolescents who have the tendency to make irresponsible financial decisions, consequently have to deal with negative outcomes in their adult lives. For example, a considerable amount of student loans or credit card debt accumulated by young consumers could disrupt their ability to accumulate wealth. Thus, the comprehension of financial concepts among the young is crucial for their consumer protection. Policymakers have to be oriented towards efficient creation of financial education programs targeting young people, and towards developing legislation on consumer protection (Lusardi, Mitchell \& Curto, 2010).

Financial education may be particularly beneficial in preparing young people for financial challenges ahead. Financial education stands for the general understanding of financial terminology, such as income, expense, debt, credit, money management and knowing how to spend, save and invest. The foremost aim of financial education is to increase financial literacy (Johnson \& Sheradden, 2007) and to protect adolescents from making wrong financial decisions, as well as guide them to the right ones.

Young adults with lower levels of financial literacy tend to have issues dealing with debt and are not prone to stock market participation, financial planning, wealth accumulation or successful retirement planning (Lusardi, Mitchell \& Curto, 2010). On the other hand, financial knowledge can improve adolescents' self-reported behaviour, so that, for example, tracking expenses and saving money increase their confidence when making financial decisions (Johnson \& Sheradden, 2007) and improve their credit behaviour (Urban et al., 2018). Moreover, possible benefits of financial literacy among young adults are recognised through the improvement of credit scores or the reduction of non-student debt and default rates (Consumer Financial Protection Bureau [CFPB], 2019).

Previously conducted research found that financial education not only improves financial literacy and financial behaviour, but it also improves financial capability. According to Hilgert and others (2003), financial knowledge has a significant positive impact on the practice of desirable financial behaviour among adolescents. Hastings, Madrian and Skimmyhorn (2013) also emphasized that financial education should be included in high-school curricula in order to improve their financial capability, so that they could adopt positive financial habits through the traditional educational system. Financial education should provide various benefits for adolescents' financial capability (McCormick, 2009). Higher levels of financial knowledge make adolescents more educated and informed about consumer finance topics in general. Consequently, adolescents who invest in their financial knowledge will have a better understanding of the concept of time, the value of money, banking, taxes, etc. In addition, they will understand how to use insurance efficiently, how to manage money and assets, avoid credit and make investments. Finally, financially educated individuals can use the acquired financial knowledge to make their own budget plans and to implement and evaluate various financial decisions.

Research in the efficiency of financial education in general indicates improvement in financial knowledge (Peng et al., 2007; Borden et al., 2008), which then implies improvement in financial behaviour (Lusardi \& Tufano, 2015; Lusardi \& Mitchell, 2017). According to Brown and others (2014), young people who attended

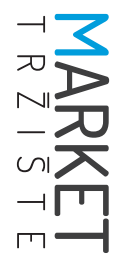


financial education programmes had higher relative credit scores in comparison to those who did not. Therefore, financially literate students will be more aware of their financial obligations, account balances and debt repayment statuses. Furthermore, Walstad, Rebeck and MacDonald (2010) confirmed the effectiveness of financial education programs and concluded that adolescents' financial literacy increased, regardless of the type of the course and its characteristics.

On the other hand, some studies concluded that financial education did not have an impact on financial literacy on a higher scale. According to Mandell and Klein (2009), students who participated in a consumer finance workshop were not financially more literate than those who did not participate in it (as cited in Xu \& Zia, 2012). What is more, Gale and Levine (2011) also found no evidence of positive influence of financial education on the increase of financial literacy levels, not even through traditional channels.

Evidently, there is still no consensus regarding the implementation of financial education in the context of creating and supporting the development of youth financial capability, which is considered crucial for building financially capable consumers (CFPB, 2019). Most financial education programs are not systemic, and are school-based (but on an ad hoc basis) (Yoong \& Ferreira, 2013; Lučić, Brečić \& Barbić, 2018). Also, financial education programs are not standardized, so different programs provide education with various levels of quality and duration. This might be an explanation for different outcomes when it comes to financial education performance.

Due to serious problems caused by a lack of financial literacy, the implementation of financial education programs is crucial for increasing the level of financial literacy. Most current programs targeted at adolescents take place at schools and their main purpose is to enhance the knowledge of personal finances and improve money management (Bucciol \& Veronesi, 2014). According to Amagir and others (2018), financial education programs which take place at tradi- tional educational institutions could upgrade children's and adolescents' financial knowledge and attitudes, thus it is essential that they start before high school. Financial education should be included as a core subject within elementary school syllabi (Morton, 2005; Beck \& Garris, 2019).

Financial education programs, according to Carlin and Robinson (2012), have a significant impact on adolescents' behaviour in the context of saving and credit. Also, participants in financial education programmes show more success in managing their debts as well. Becchetti, Caiazza \& Coviello (2013) stated that financial education programs have an impact on the understanding of economic news in the media, and Lührmann, Serra-Garcia and Winter (2015) noted less impulsiveness in purchasing as a positive outcome related to a financial education program (as cited in Sansone, Rossi \& Fornero, 2019). In the context of policy, it is crucial for all financial education programs to be regulated on the institutional level and this kind of regulation leads to a standardized approach in the context of adolescents' financial education. Otherwise, if adolescents continue acquiring financial education only within their families, serious differences and knowledge gaps could appear between them (Sansone, Rossi \& Fornero, 2019). Therefore, the introduction of financial education programs in traditional education institution curricula is crucial for establishing equal financial literacy among adolescents (McCormick, 2009).

A sustainable financial education program, according to Kozup and Hogarth (2008), starts with goal identification. The goals could be, for example, becoming a homeowner, avoiding or reducing debt, or making a financial plan for the retirement. With efficiently defined financial goals, a financial education program could easily be adjusted to the needs and preferences of specific consumers. In order to achieve meaningful results, financial education programs should be designed according to attendants' characteristics. In addition, such programs should be focused on maintaining attendants' motivation, 
and they should be performed at a younger age. According to Hathaway and Khatiwada (2008), the most efficient way of designing programs is to identify the characteristics and performances of attendants and the mandatory consumer finance topics that should be included in the program. Also, according to Lucey (2007), financial education design should be customized. Grody and others (2008) noted that the program design needs to be directly related to adolescents' financial environment. Furthermore, in order for the education program to be efficient, it is crucial to ensure effective motivation. Mandell and Klein (2007) concluded that attendants with low levels of financial literacy usually have problems with sustaining their motivation during the program. Without appropriate motivation, adolescents will not be able to absorb the necessary consumer finance knowledge.

A successful financial education program has various benefits. As mentioned, financial education programs could lead to equal financial literacy distribution among adolescents. As financial knowledge is acquired mainly in the family, from peers or the media, it is very important to introduce and implement financial education in schools to clarify all ambiguities, to standardize financial knowledge, and to make it available to all adolescents regardless of their social environment. Furthermore, financial education programs mostly have a positive influence on financial knowledge and, consequently, financial literacy among adolescents. In order to prevent them from making ill-informed financial decisions, it is crucial to educate the young in the context of consumer finances and finances in general, even before they enter the financial market and encounter financial proposals and offers. Due to possible benefits of financial education programs and their potentially positive impact on the level of financial literacy, it is imperative to invest in the financial education of adolescents and to investigate its impact on the subsequent financial knowledge and financial behaviour (Lusardi, Mitchell \& Curto, 2010).
According to a research (2017) conducted by Raddon, a Fiserv company, most adolescents consider financial education programs to be very important for strengthening financial literacy, but only one-third of the surveyed adolescents participated in some type of financial education programs. Moreover, according to Business Insider Intelligence research (2019), adolescents want to improve their financial understanding. In other words, they are seeking tools that could improve their financial literacy. They are interested in learning about spending comparisons, financial wellness scores and best practice for saving money. Consequently, adolescents who are interested in increasing their financial understanding have a higher level of financially literacy and financial knowledge.

A higher level of financial literacy, as mentioned above, leads to a better understanding of bank accounts functioning (Xiao \& O'Neill, 2016). According to a research from Synchrony Financial (2018), the usage of debit cards is common among adolescents. However, checking and savings accounts or mobile wallets are not so widespread. Adolescents who pay their own bills are likely to have prosperous financial futures and understand the concept of debt and saving better. According to Lincoln Financial Group (2016), most adolescents have savings accounts. The Center for Generational Kinetics (2017) confirmed that adolescents have their savings accounts before the age of 10 . Consequently, higher rates of savings accounts among adolescents indicate a greater understanding of the saving concept and a higher level of financial literacy.

\subsection{Gender differences in financial literacy and efficiency of financial education programs among adolescents}

Family has great impact on adolescents' financial literacy, not only as a source of information but also in the context of gender. Family as a social structure shapes gender-related experiences and attitudes toward money. According to 


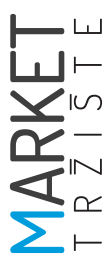

Greene (1990), adolescents' financial behaviour and assumptions, which they are to develop in their adult lives, are formed in childhood based on their parents' gendered financial roles. Furthermore, men are more successful in financial decision making because women face financial complications and dilemmas, and struggle on a larger scale. Moreover, male students have higher levels of general financial knowledge than female students do (Danes \& Haberman, 2007).

Nonetheless, the implementation of financial education programs requires considering differences in the context of genders. Although male students demonstrate better knowledge before entering the programs, female students, in general, gain more knowledge of the areas of credit and investment during the program. Also, men have more confidence while making money decisions and reinforce their existing knowledge during educational programs. On the other hand, female students develop better knowledge about financial areas unfamiliar to them before the education. Female students have higher consciousness levels about managing money and a higher awareness of its benefits in their adult lives. After participating in programs, male students are more likely to achieve financial goals than female students are, who are more successful in managing budgets and comparing prices. Also, female students have shown greater tendencies to discuss financial matters with their family members than male have (Danes \& Haberman, 2007).

According to Chen and Volpe (2002), men are more interested in and more enthusiastic about acquiring financial knowledge than women are. Through their research, they confirmed that men have greater knowledge of personal finances and finances in general. Additionally, men are more confident about their knowledge and understand the importance of financial knowledge to a larger extent. Furthermore, Fonseca and others (2012) stated that men and women have different approaches to financial knowledge and, consequently, financial literacy, and that there was a difference between their roles in the household. While men are responsible for making financial decisions and the financial future of the household, women are responsible for other functions in the household, such as housework or taking care of children. Women and men with similar education levels take on the same number of financial responsibilities relative to their partners. In other words, financial education is crucial for increasing financial responsibilities in the household. Higher levels of financial knowledge, despite gender, will lead to successful and prosperous household financial decision making. Therefore, financial decision making among adolescents should depend on the level of financial education on a larger scale. However, by following research, male adolescents have an advantage in acquiring financial knowledge.

\section{METHODOLOGY}

The "My Money, my future" project is a non-profit financial education program developed and implemented in 2015 for high school students in Croatia. The main purpose of the project was to increase low levels of adolescents' financial literacy. University of Zagreb professors teamed up and authored a high school textbook, which was approved by the Education and Teacher Training Agency and introduced in schools. In addition to being printed twice in 5000 copies and delivered to all applicant schools, the book is permanently available for free online download.

Apart from the book, the project included numerous workshops for both teachers and students on the topic of financial literacy. The workshop for students lasted for three hours and covered four areas: consumer protection, money, financial institutions and products, and financial budgeting and planning.

The data was collected from a purposive sample of teenagers who participated in the "My money, my future" program from October 2016 to February 2018. Two pilot workshops were conducted prior to the main sample collection to ensure that the workshop intervention and 
the questionnaire were understandable to the target group. In two and a half years, the authors conducted 30 workshops in 10 Croatian cities and collected the total of 420 questionnaires, out of which 330 had all required parts filled out, thereby becoming eligible for data analysis.

The questionnaire used to collect the data was a three-part tool. The first part consisted of questions regarding the socio-demographic profile of the respondents. The section included questions about gender, age, interest in personal finance, perception of knowledge on personal finance, formal and informal types of education they participated in, saving habits, education levels of their parents, etc. Questions regarding saving habits and past education participation had dichotomous scales, whereas interest and perception of self-knowledge were tested on a 5-point Likert scale. The second and third parts consisted of pre- and post-financial knowledge tests, each with 10 yes-or-no questions derived from the questionnaire developed by Lusardi and Mitchel (2011).

Based on literature review, this paper hypothesizes the following: (1) book-based financial education will increase the level of acquired financial literacy and improve the general financial behaviour of participants (Peng et al., 2007; Borden et al. 2008; Lusardi \& Tufano, 2015; Lusardi \& Mitchell, 2017); (2) there is a significant difference between female and male students in terms of their success in acquiring financial knowledge (McCormick, 2009); (3) students who receive financial education at an earlier age will be more successful in acquiring financial knowledge (Center for Generational Kinetics, 2017).

\section{RESULTS}

The sample consists mainly of high school students enrolled in general grammar school programs (38.79\%), technical vocational schools (28.79\%), economics programs (12.12\%), private general grammar school programs (7.58\%), language grammar school programs (4.55\%) and other. All respondents were between 15 and 19 years of age, and the average age was 17.46. The greatest share in the sample was age 18 (45.45\%) and 17 (27.58\%). In terms of gender, $49.09 \%$ of participants in the analysed sample $(\mathrm{N}=330)$ were female. Most teenagers were members of families with moderate to relatively good financial statuses, which is determined by their parents' educational levels.

The respondents' average grade was 4.1 (female 4.24; male 3.95) and the average grade in mathematics was 3.41 (female 3.54; male 3.31), indicating that the sample mainly consisted of very good students and average math students. The average reported interest for the field of personal finance was 3.87, with male respondents showing somewhat larger interest, but without statistical significance. In terms of the perception of their knowledge on personal finance, female respondents believe, statistically significantly, that they know much more than

TABLE 1: Educational structure of respondents' parents

\begin{tabular}{|c|c|c|c|c|c|}
\hline $\begin{array}{c}\text { School } \\
\text { Mother }\end{array}$ & Primary & High School & College & University & Total \\
\hline & 6 & 146 & 66 & 98 & 316 \\
\hline & $1.90 \%$ & $46.20 \%$ & $20.89 \%$ & $31.01 \%$ & \\
\hline $\begin{array}{l}\text { School } \\
\text { Father }\end{array}$ & Primary & High School & College & University & Total \\
\hline & 2 & 154 & 68 & 89 & 313 \\
\hline & $0.64 \%$ & $48.73 \%$ & $21.52 \%$ & $28.16 \%$ & \\
\hline
\end{tabular}

Source: Authors' own calculation 
TABLE 2: Statistical significance test of predictors of larger levels of knowledge between female and male students

\begin{tabular}{|c|c|c|c|c|c|c|}
\hline \multicolumn{2}{|c|}{ Gender } & Female & Male & Total & & \\
\hline \multicolumn{2}{|l|}{ N } & 162 & 168 & 330 & & \\
\hline \multicolumn{2}{|l|}{ Percentage } & $49.09 \%$ & $50.91 \%$ & & & \\
\hline \multicolumn{2}{|l|}{ Interest } & & & & $p$-value ${ }^{* *}$ & 0.896048 \\
\hline \multicolumn{2}{|l|}{ Mean } & 3.78 & 3.95 & 3.87 & & \\
\hline \multicolumn{2}{|c|}{ SD } & .966 & 1.037 & 1.004 & & \\
\hline \multicolumn{2}{|c|}{ Self-knowledge } & & & & $p$-value ${ }^{* *}$ & 0.046883 \\
\hline \multicolumn{2}{|c|}{ Mean } & 3.18 & 3.10 & 3.15 & & \\
\hline \multicolumn{2}{|l|}{ SD } & .943 & .943 & .893 & & \\
\hline \multicolumn{2}{|l|}{ Saving } & & & & $p$-value* & 0.897468 \\
\hline \multicolumn{2}{|l|}{ Frequency } & 123 & 128 & 251 & & \\
\hline \multicolumn{2}{|l|}{ percent } & $75.92 \%$ & $76.19 \%$ & $76.06 \%$ & & \\
\hline \multicolumn{2}{|l|}{ Account } & & & & p-value* & 0.020621 \\
\hline \multicolumn{2}{|l|}{ Frequency } & 73 & 97 & 170 & & \\
\hline \multicolumn{2}{|l|}{ percent } & $45.06 \%$ & $57.73 \%$ & $51.51 \%$ & & \\
\hline & \multicolumn{6}{|c|}{ * Significance of Fisher's Exact Test of Independence } \\
\hline & \multicolumn{6}{|c|}{ ** Significance of Levene's Test for Equality of Variances } \\
\hline
\end{tabular}

Source: Authors' own calculation

TABLE 3: Regression model - Financial knowledge before the workshop

\begin{tabular}{|c|c|c|c|c|}
\hline \multicolumn{5}{|c|}{ Model Summary } \\
\hline Model & $\mathbf{R}$ & R square & $\begin{array}{c}\text { Adjusted R } \\
\text { square }\end{array}$ & $\begin{array}{c}\text { Std. Error of } \\
\text { the estimate }\end{array}$ \\
\hline 1 & $.274^{\mathrm{a}}$ & .075 & .057 & 1.527 \\
\hline \multicolumn{5}{|c|}{} \\
\hline
\end{tabular}

Source: Authors' own calculation

their male equivalents. Male respondents report more opened accounts with a statistical significance, and more savings with no significance.

The knowledge tested before the workshop was examined in a simple linear regression to investigate possible predictors of financial knowledge, including interest $(0.157, p=0.009)$, previous financial education $(0.139, p=0.15)$ and ownership of a bank account $(0.114, p=0.042)$.

The main test of the difference of knowledge levels before and after the workshop confirmed larger levels of financial knowledge of adolescents after the education ( $t=-2.807, p=0.005$ ). The difference in before/after knowledge is sta- 
TABLE 4: ANOVA - Financial knowledge before the workshop

\begin{tabular}{|c|c|c|c|c|c|c|}
\hline \multicolumn{7}{|c|}{ ANOVA } \\
\hline \multicolumn{2}{|c|}{ Model } & \multirow{2}{*}{$\begin{array}{c}\begin{array}{c}\text { Sum of } \\
\text { squares }\end{array} \\
59.089\end{array}$} & \multirow[t]{2}{*}{ df } & \multirow{2}{*}{$\begin{array}{c}\begin{array}{c}\text { Mean } \\
\text { square }\end{array} \\
9.848\end{array}$} & \multirow{2}{*}{$\begin{array}{r}\mathbf{F} \\
4.222\end{array}$} & \multirow{2}{*}{$\begin{array}{r}\text { Sig. } \\
.000^{b}\end{array}$} \\
\hline 1 & Regression & & & & & \\
\hline & Residual & 727.745 & 312 & 2.333 & & \\
\hline & Total & 786.834 & 318 & & & \\
\hline \multicolumn{7}{|c|}{ a. Dependent variable: KNOWBEFORE } \\
\hline
\end{tabular}

Source: Authors' own calculation

TABLE 5: Standardized and unstandardized coefficients - Financial knowledge before the workshop

\begin{tabular}{|c|c|c|c|c|c|c|}
\hline \multicolumn{7}{|c|}{ Coefficients $^{a}$} \\
\hline \multirow{2}{*}{\multicolumn{2}{|c|}{ Model }} & \multicolumn{2}{|c|}{$\begin{array}{l}\text { Unstandardized } \\
\text { coefficients }\end{array}$} & \multirow{2}{*}{$\begin{array}{c}\begin{array}{c}\text { Standardized } \\
\text { coefficients }\end{array} \\
\text { Beta }\end{array}$} & \multirow[t]{2}{*}{$\mathbf{t}$} & \multirow[t]{2}{*}{ Sig } \\
\hline & & B & Std. Error & & & \\
\hline \multirow[t]{7}{*}{1} & (Constant) & 5.089 & .784 & & 6.494 & .000 \\
\hline & SELFKNOW & -.013 & .105 & -.008 & -.126 & .899 \\
\hline & INTREST & .249 & .095 & .157 & 2.618 & .009 \\
\hline & FINEDU & .589 & .241 & .139 & 2.444 & .015 \\
\hline & SAVE & .228 & .206 & .061 & 1.104 & .270 \\
\hline & GRADEAVRG & -.017 & .158 & -.006 & -.105 & .916 \\
\hline & ACCOUNT & .357 & .174 & .114 & 2.046 & .042 \\
\hline
\end{tabular}

Source: Authors' own calculation

TABLE 6: Regression model - Financial knowledge after the workshop

\begin{tabular}{|c|c|c|c|c|}
\hline \multicolumn{5}{|c|}{ Model Summary } \\
\hline Model & R & R square & $\begin{array}{c}\text { Adjusted R } \\
\text { square }\end{array}$ & $\begin{array}{c}\text { Std. Error of } \\
\text { the estimate }\end{array}$ \\
\hline 1 & $.302^{\mathrm{a}}$ & .091 & .089 & 1.385 \\
\hline a. Predictors: (Constant), KNOWBEFORE
\end{tabular}

Source: Authors' own calculation 
TABLE 7: ANOVA - Financial knowledge after the workshop

\begin{tabular}{|c|c|c|c|c|c|c|}
\hline \multicolumn{7}{|c|}{ ANOVA $^{a}$} \\
\hline \multicolumn{2}{|r|}{ Model } & $\begin{array}{l}\text { Sum of } \\
\text { squares }\end{array}$ & df & $\begin{array}{l}\text { Mean } \\
\text { square }\end{array}$ & $\mathbf{F}$ & Sig. \\
\hline \multirow[t]{3}{*}{1} & Regression & 63.459 & 1 & 63.459 & 33.071 & $.000^{\mathrm{b}}$ \\
\hline & Residual & 631.302 & 329 & 1.919 & & \\
\hline & Total & 694.761 & 330 & & & \\
\hline \multicolumn{7}{|c|}{ a. Dependent variable: KNOWAFTER } \\
\hline \multicolumn{7}{|c|}{ b. Predictors: (Constant), KNOWBEFORE } \\
\hline
\end{tabular}

Source: Authors' own calculation

TABLE 8: Standardized and unstandardized coefficients - Financial knowledge after the workshop

\begin{tabular}{|c|c|c|c|c|c|c|}
\hline \multicolumn{7}{|c|}{ Coefficients $^{a}$} \\
\hline \multirow{2}{*}{\multicolumn{2}{|c|}{ Model }} & \multicolumn{2}{|c|}{$\begin{array}{c}\text { Unstandardized } \\
\text { coefficients }\end{array}$} & \multirow{2}{*}{$\begin{array}{c}\text { Standardized } \\
\text { coefficients } \\
\text { Beta }\end{array}$} & \multirow[t]{2}{*}{$\mathbf{t}$} & \multirow[t]{2}{*}{ Sig. } \\
\hline & & B & Std. Error & & & \\
\hline \multirow[t]{2}{*}{1} & (Constant) & 4.878 & .321 & & 15.172 & .000 \\
\hline & KNOWBEFORE & .281 & .049 & .302 & 5.751 & .000 \\
\hline
\end{tabular}

Source: Authors' own calculation

tistically significant and greater within the group of male respondents.

\section{DISCUSSION AND CONCLUSION}

The aim of the study was to examine the purpose of financial education in terms of financial literacy of adolescents and to test the efficiency of the high school textbook developed through the "My money, my future" programme. Moreover, the purpose was to detect the predictors of financial knowledge before the workshop, as well as the characteristics of the young who performed best on the financial knowledge test, in order to further investigate the process of financial education effectiveness.
The findings of the conducted research proved that financial interventions based on systemized financial literacy literature contribute to the level of acquired financial knowledge among the youth. The conclusion drawn therefrom follows previous research that showed how financial education in general indicates improvement in financial knowledge (Peng et al., 2007; Borden et al. 2008) and leads to positive financial behaviour (Lusardi \& Tufano, 2015; Lusardi \& Mitchell, 2017). Consequently, it can be noted that financial intervention, like financial education programs aimed at adolescents, leads to the improvement of their financial literacy levels, which is in accordance with past research.

Moreover, the majority of sampled high-school students reported engagement in saving behaviour, and more than half of them stated that 
they had open bank accounts. The conclusion is in line with a research study from Synchrony Financial (2018) - the majority of adolescents use debit cards. Furthermore, as respondents are members of Generation Z, this conclusion is related to findings on how most adolescents save, primarily for a specific goal (TransUnion, 2017). Adopting saving behaviour at a younger age could lead to greater financial stability in the future. Also, it presents a factor of responsible financial behaviour and offers concepts indispensable for obtaining higher levels of financial literacy.

Female respondents reported higher levels of self-perceived financial knowledge. This conclusion diverges from the relevant past research which suggested that men had greater knowledge of personal finances and finances in general, and were more confident about their knowledge than women (Chen \& Volpe, 2002). It was also concluded that male respondents in general exhibited the following: more knowledge before entering the programs, more confidence while making money-related decisions and more success in reinforcing their existing knowledge during financial education. On the other hand, men gained more knowledge of credit and investment and learned significantly more about finances in areas they had been unfamiliar with before the program (Danes \& Haberman, 2007). Although there are differences between female and male students in the context of financial knowledge, financial education is still required for both genders.

Interest, previous financial education and ownership of a bank account were found to be significant predictors of higher levels of knowledge among adolescents. In other words, adolescents who scored higher in acquiring financial knowledge also reported higher levels of motivation for learning the concepts essential in the context of financial literacy (McCormick, 2009). Previous financial education proved to have a positive influence on increasing the levels of financial knowledge and, according to the Center for Generational Kinetics (2017), adolescents are aware of the importance of financial education programs for empowering financial knowledge. And lastly, adolescents who owned a bank account indicated higher levels of financial experience and familiarity with the financial market, which consequently led to higher levels of financial knowledge.

Finally, research findings suggest that the level of financial knowledge after the participation in the financial education workshop was significantly higher compared to such knowledge before the program. The difference in acquired financial knowledge before and after education was larger among male participants than among female participants. Our conclusion confirms the importance of financial education programs with the purpose of enhancing the level of financial literacy among adolescents in the future.

The type of sample represents a limitation of the research study, as it included only high school students. Thus, in future research elementary school students should be included as well. What is more, due to the importance of financial education at an early age, it should be implemented as a core subject in elementary school syllabi (Morton, 2005; Beck \& Garris, 2019). Additionally, the absence of development control of financial literacy among respondents' years after the workshop (e.g. when they enter college) presents another limitation of the study at hand. Consequently, future research studies should examine how financial education in high school affects financial literacy of college students. Lastly, this research study was conducted on the territory of the Republic of Croatia, so future research efforts could be expanded to other countries of the European Union.

\section{Acknowledgement}

This paper is based on research undertaken in the frame of the Project of the Croatian Science Foundation - UIP-2019-04-3580; EfFICACY - Empowering financial capability of young consumers through education and behavioural intervention

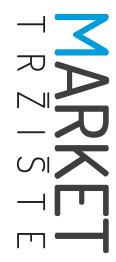




\section{REFERENCES}

1. Ali, P., McRae, C. H., \& Ramsay, I. (2014). Financial literacy and financial decision-making of Australian secondary school students. Australian Business Law Review, 42(3), 228-233.

2. Amagir, A., Groot, W., Maassen van den Brink, H., \& Wilschut, A. (2018). A review of financial-literacy education programs for children and adolescents. Citizenship, Social and Economics Education, 17(1), 56-80.

3. Barbić, D., Lučić, A., \& Chen, J. M. (2019). Measuring responsible financial consumption behaviour. International Journal of Consumer Studies, 43(1), 102-112.

4. Beck, J. J., \& Garris, R. O. (2019). Managing Personal Finance Literacy in the United States: A Case Study. Education Sciences, 9(2), 129.

5. Berkup, S. B. (2014). Working with generations $X$ and $Y$ in generation $Z$ period: Management of different generations in business life. Mediterranean Journal of Social Sciences, 5(19), 218-224.

6. Borden, L. M., Lee, S. A., Serido, J., \& Collins, D. (2008). Changing college students' financial knowledge, attitudes, and behavior through seminar participation. Journal of Family and Economic Issues, 29(1), 23-40.

7. Braunstein, S., \& Welch, C. (2002). Financial literacy: An overview of practice, research, and policy. Federal Reserve Bulletin, 88(11), 445-457.

8. Brown, A., Collins, J. M., Schmeiser, M. D., \& Urban, C. (2014). State mandated financial education and the credit behavior of young adults. (No. 2014-68). Board of Governors of the Federal Reserve System (US). Available at: https://www.cthousegop.com/wp-content/uploads/2015/06/ State-Mandated-Financial-Education-and-the-Credit-Behavior-of-Young-Adults-Federal-Reserve-Board-2014.pdf

9. Bucciol, A., \& Veronesi, M. (2014). Teaching children to save: What is the best strategy for lifetime savings? Journal of Economic Psychology, 45, 1-17.

10. Business Insider Intelligence (2019). Banking and payments for Gen Z. Available at: https://pedestriangroup.com.au/wp-content/uploads/2019/08/bii_bankingandpaymentsforgenz_2019.pdf

11. Center for Generational Kinetics (2017). The State of Gen Z 2017. Available at: https://genhq.com/ wp-content/uploads/2017/04/The-State-of-Gen-Z-2017-White-Paper-c-2017-The-Center-forGenerational-Kinetics.pdf

12. Center for Generational Kinetics (2018). The State of Gen Z 2018. Available at: https://genhq. com/wp-content/uploads/2018/10/State-of-Gen-Z-2018.pdf?inf_contact_key=b4b0f67ed8ed53ee3bb1e8019e212ecd447d8eaa43673fdaa114662fd31ef250

13. Chen, H., \& Volpe, R. P. (2002). Gender differences in personal financial literacy among college students. Financial Services Review, 11(3), 289-307.

14. Consumer Financial Protection Bureau (2019). A review of youth financial education: Effects and evidence. Available at: https://www.consumerfinance.gov/data-research/research-reports/review-youth-financial-education-effects-and-evidence/

15. Croatian National Bank (2015). Mjerenje financijske pismenosti i financijske uključenosti u Hrvatskoj. Available at: http://old.hnb.hr/priopc/2016/hr/hp04022016_prezentacija.pdf.

16. Danes, S. M., \& Haberman, H. (2007). Teen financial knowledge, self-efficacy, and behavior: A gendered view. Journal of Financial Counseling and Planning, 18(2), 48-60.

17. Fonseca, R., Mullen, K. J., Zamarro, G., \& Zissimopoulos, J. (2012). What explains the gender gap in financial literacy? The role of household decision making. Journal of Consumer Affairs, 46(1), 90 106.

18. Gaidhani, S., Arora, L., \& Sharma, B. K. (2019). Understanding the Attitude of Generation Z Towards Workplace. International Journal of Management, Technology and Engineering, 9(1), 2804. 
19. Gale, W. G., \& Levine, R. (2010). Financial literacy: What works? How could it be more effective? Available at: http://crr.bc.edu/wp-content/uploads/2011/03/FSP-2011-1.pdf

20. Gerhard, P., Gladstone, J. J., \& Hoffmann, A. O. (2018). Psychological characteristics and household savings behavior: The importance of accounting for latent heterogeneity. Journal of Economic Behavior and Organization, 148(1), 66-82.

21. Hastings, J. S., Madrian, B. C., \& Skimmyhorn, W. L. (2013). Financial literacy, financial education and economic outcomes. Annual Review of Economics, 5 (2013), 347-373.

22. Hilgert, M. A., Hogarth, J. M., \& Beverly, S. G. (2003). Household financial management: The connection between knowledge and behavior. Federal Reserve Bulletin, 89(7), 309-322.

23. Johnson, E., \& Sherraden, M. S. (2007). From financial literacy to financial capability among youth. Journal of Sociology \& Social Welfare, 34(3), 119-146.

24. Lewis, S., \& Messy, F. A. (2012). Financial Education, Savings and Investments: An Overview. Available at: https://doi.org/10.1787/5k94gxrw760v-en

25. Lincoln Financial Group (2016). Gen Z and the Challenges/Opportunities Driving Their Financial Mindset. Available at: https://drive.google.com/file/d/0B1Axm9XHqBDgek10eTBkb3BKb051R3U4aXZKKOOdONjRzVEZB/view

26. Lučić, A., Brečić, R., \& Barbić, D. (2018). Analiza svjetskih praksi u području financijske pismenosti i percepcija nastavnika o uvođenju financijske pismenosti u školske kurikule. In: J. Filipović and R. Brečić (Eds.), Financijska pismenost i socializacija djece kao potrošača. Zagreb: Ekonomski fakutlet Zagreb.

27. Luksander, A., Béres, D., Huzdik, K., \& Németh, E. (2014). Analysis of the factors that influence the financial literacy of young people studying in higher education. Public Finance Quarterly, 59(2), 220-241.

28. Lusardi, A., \& Mitchell, O. (2017). How Ordinary Consumers Make Complex Economic Decisions: Financial Literacy and Retirement Readiness. Quarterly Journal of Finance (QJF), 7(3), 1-31.

29. Lusardi, A., \& Mitchell, O. S. (2011). Financial literacy around the world: an overview. Journal of Pension Economics and Finance, 10(4), 497-508.

30. Lusardi, A. (2015). Financial Literacy Skills for the 21st Century: Evidence from PISA. Journal of Consumer Affairs, 49(3): 639-659.

31. Lusardi, A., \& Tufano, P. (2015). Debt literacy, financial experiences, and over indebtedness. Journal of Pension Economics and Finance, 14(4), 332-368.

32. Lusardi, A., Mitchell, O. S., \& Curto, V. (2010). Financial literacy among the young. Journal of Consumer Affairs, 44(2), 358-380.

33. Mandell, L., \& Klein, L. S. (2007). Motivation and financial literacy. Financial Services Review, 16(2), 105-116.

34. McCormick, M. H. (2009). The Effectiveness of Youth Financial Education: A Review of the Literature. Journal of Financial Counseling and Planning, 20(1), 70-83.

35. Moffitt, T. E., Arseneault, L., Belsky, D., Dickson, N., Hancox, R. J., Harrington, H., Houts, R., Poulton, R., Roberts, B. W., Ross, S., Sears, M.R., Thomson, W.M., \& Caspi, A. (2011). A gradient of childhood self-control predicts health, wealth, and public safety. Proceedings of the national Academy of Sciences, 108(7), 2693-2698.

36. Morton, J. (2005). The Interdependence of Economic and Personal Finance Education. Social Education, 69 (2), 66-70.

37. Nielsen (2015). Global Generational Lifestyles: How We Live, Eat, Play, Work and Save for Our Futures. Available at: https://www.nielsen.com/wp-content/uploads/sites/3/2019/04/global-generational-report-november.pdf 
38. Peng, T. C. M., Bartholomae, S., Fox, J. J., \& Cravener, G. (2007). The impact of personal finance education delivered in high school and college courses. Journal of Family and Economic Issues, 28(2), 265-284.

39. Raddon A Fiserv Company (2017). Generation Z: The Kids Are All Right - Executive Summary. Available at: https://www.raddon.com/sites/default/files/genz-executive-summary.pdf

40. Sansone, D., Rossi, M., \& Fornero, E. (2019). "Four Bright Coins Shining at Me": Financial Education in Childhood, Financial Confidence in Adulthood. Journal of Consumer Affairs, 53(2), 630-651.

41. Shatto, B., \& Erwin, K. (2016). Moving on from millennials: Preparing for generation Z. The Journal of Continuing Education in Nursing, 47(6), 253-254.

42. Synchrony Financial (2018). Understanding Gen Z: Insights on their behavior, financial knowledge and spending patterns. Available at: https://www.synchrony.com/download/2018-Understanding-Generation-Z.pdf

43. TransUnion (2017). Generation Z's Financial Report Card. Available at: https://www.transunion. com/docs/TUC_GenZReport_FINAL_06.22.17_US\%5B2\%5D.pdf

44. Urban, C., Schmeiser, M., Collins, J. M., \& Brown, A. (2018). The effects of high school personal financial education policies on financial behavior. Economics of Education Review, 101786.

45. Vision Critical (2019). The Everything Guide to Generation Z. Available at: https://www.visioncritical.com/resources/the-everything-guide-to-gen-z

46. Vojvodić, K. (2018). Generation Z in Brick-and-Mortar stores: A review and research propositions, Business Excellence, 12(3), 105-120.

47. Walstad, W. B., Rebeck, K., \& MacDonald, R. A. (2010). The effects of financial education on the financial knowledge of high school students. Journal of Consumer Affairs, 44(2), 336-357.

48. Wiedmer, T. (2015). Generations do differ: Best practices in leading traditionalists, boomers, and generations $X, Y$, and Z. Delta Kappa Gamma Bulletin, 82(1), 51-56.

49. Xiao, J. J., \& O'Neill, B. (2016). Consumer financial education and financial capability. International Journal of Consumer Studies, 40(6), 712-721.

50. Xu, L., \& Zia, B. (2012). Financial literacy around the world: an overview of the evidence with practical suggestions for the way forward. The World Bank. Available: https://openknowledge. worldbank.org/bitstream/handle/10986/9322/WPS6107.pdf?sequence=1

51. Yoong, J., \& Ferreira, V. R. D. M. (2013). Improving financial education effectiveness through behavioural economics: OECD key findings and way forward. OECD Publishing. Available: https:// www.oecd.org/daf/fin/financial-education/TrustFund2013_OECDImproving_Fin_Ed_effectiveness_through_Behavioural_Economics.pdf 